\title{
PENINGKATAN HASIL BELAJAR MENGGUNAKAN PENDEKATAN PROBLEM SOLVING PADA SISWA SMK
}

\author{
Riki Andriansyah ${ }^{1}$, Luvy Sylviana Zanthy ${ }^{2}$ \\ 1,2 Fakultas Pendidikan Matematika dan Sains, IKIP SILIWANGI \\ ${ }^{1}$ rikiandriansyah.ra@gmail.com ${ }^{2}$ zanthy23@yahoo.com
}

\begin{abstract}
This research was conducted to observe the improvement in learning outcomes of SMK students who applied a problem solving approach. This research is in the form of classroom action research conducted at SMK Negeri 1 Cimahi in class XII Cooling and Air Conditioning Techniques A. The methods applied for data collection are observation, field notes, documentation, tests. The results of this study indicate the influence of problem solving learning on student learning outcomes and the value obtained by students continues to increase each cycle. The percentage of student learning outcomes with a value above 7 before being given an action is $13 \%$ and after being given the percentage action it continues to increase in each cycle. The percentage is $56 \%$ in the initial cycle, then in the second cycle the percentage is $81 \%$. So that the problem solving approach appears to have an influence on student learning outcomes.
\end{abstract}

Keywords: Problem Solving Approach, Learning Outcomes

\begin{abstract}
Abstrak
Penelitian ini dilakukan untuk mengamati peningkatan hasil belajar siswa SMK yang menerapkan pendekatan problem solving. Penelitian ini berupa penelitian tindakan kelas yang dilakukan di SMK Negeri 1 Cimahi pada kelas XII Teknik Pendingin dan Tata Udara A. Metode yang diterapkan untuk pengumpulan datanya adalah observasi, catatan lapangan, dokumentasi, tes. Pada hasil penelitian ini menunjukkan adanya pengaruh pembelajaran problem solving pada hasil belajar siswa dan nilai yang didapat siswa terus meningkat setiap siklusnya. Persentase hasil belajar siswa dengan nilai diatas 7 pada sebelum diberi tindakan adalah $13 \%$ dan setelah diberi tindakan persentasenya terus mmeningkat pada setiap siklusnya. Persentasenya adalah $56 \%$ pada siklus awal, kemudian pada siklus kedua persentasenyaa adalah $81 \%$. Sehingga terlihat pendekatan problem solving memiliki pengaruh pada hasil belajar siswa.
\end{abstract}

Kata Kunci: Pendekatan Problem Solving, Hasil Belajar

How to cite: Andriansyah, R., \& Zanthy, LS. (2019). Peningkatan Hasil Belajar Menggunakan Pendekatan Problem Solving pada Siswa SMK. JPMI - Jurnal Pembelajaran Matematika Inovatif, X (X), XX-XX.

\section{PENDAHULUAN}

Matematika ialah mata pelajaran yang sudah dipelajari bahkan pada jenjang pendidikan usia dini. Sehingga, hal itu memperlihatkan bahwa matematika sangat penting untuk dipelajari. Bahkan matematika juga disebut-sebut sebagai ratunya ilmu, tidak seperti ilmu pendidikan yang lainnya, yang bergantung pada ilmu matematika seperti mata pelajaran fisika, kimia, dan yang lainnya. 
Namun, dalam kenyataannya kebanyakan siswa menganggap matematika susah untuk dipahami, sehingga mengakibatkan siswa malas untuk belajar, hal tersebut bersesuaian dengan pernyataan Aritonang (2008) yaitu dalam hasil pengamatannya di SMPK 1 Penabur siswa tidak berminat untuk belajar matematika. Sedangkan matematika memiliki peranan penting, diantaranya dalam mengembangkan dunia teknologi. Dan hal tersebut diantaranya dikarenakan oleh pendekatan pembelajaran yang kurang tepat. Dimana pendekatan yang sering diterapkan adalah dengan memfokuskan guru sebagai pusat pembelajaran.

Hal tersebut sesuai dengan pernyataan Syarif (2017) yang juga mengatakan bahwa penyebab permasalahan pada pendidikan Indonesia dikarenakan lebih sering menggunakan pembelajaran biasa atau pada drill and practice. Dan itu akan membuat siswa kesulitan ketika mendapatkan soal yang berbeda. Sehingga dari masalah tersebut diperlukan suatu cara yang dapat membuat siswa dapat menyelesaikan permasalahan dengan baik, dan itu memerlukan kemampuan dalam memahami masalah dan juga perencanaan solusi. sehingga meningkatkan kemampuan ini perlu dibiasakan dalam pembelajaran di sekolah.

Syarif (2017) mengatakan problem solving ialah pembelajaran yang mengharuskan siswa untuk menunjukkan keterampilan mencari informasi untuk menyusun perencanaan penyelesaian yang tepat untuk dilakukan. Dari pernyataan tersebut terlihat problem solving membuat siswa lebih aktif dalam belajar. Sehingga dalam pendekatan problem soving yang menjadi pusat pembelajarannya adalah siswa. Dari uraian di atas, maka dimlaksanakan penelitian yang berjudul Peningkatan Hasil Belajar Menggunakan Pendekatan Problem Solving Pada Siswa SMK.

\section{METODE}

Penelitian ini ialah penelitian tindakan kelas. Menurut Pangestika (2015) mengatakan bahwa langkah-langkah penelitian ini ada 7 langkah yaitu dialog awal, perencanaan tindakan, pelaksanaan, observasi, refleksi, evaluasi, dan penyimpulan. Penelitian ini dilaksanakan pada tanggal 09 November 2018 sampai dengan 16 November 2018 di SMK Negeri 1 Cimahi dengan subjek penerima tindakan adalah siswa kelas XII TPTU A yang berjumlah 32 orang.

Metode dalam pengumpulan datanya adalah 1) observasi digunakan untuk mendapatkan gambaran secara langsung pemahaman konsep matematika siswa, 2) catatan lapangan, 3) dokumentasi, 4) tes. Teknik analisis data menggunakan proses analisis data, penyajian data, dan verifikasi data.

\section{HASIL DAN PEMBAHASAN}

\section{Hasil}

Berdasarkan dari hasil penelitian yang dilakukan diperoleh data peningkatan siswa pada setiap siklusnya. Sehingga, pada penelitian ini terlihat bahwa pendekatan problem solving memiliki pengaruh terhadap hasil belajar siswa.

Tabel 1. Data Peningkatan Hasil Belajar Siswa

\begin{tabular}{ccccc}
\hline No & Hasil Belajar Siswa & Sebelum Tindakan & \multicolumn{2}{c}{ Sesudah Tindakan } \\
\cline { 4 - 5 } & & & Siklus 1 & Siklus 2 \\
\hline 1 & Hasil belajar siswa $>7$ & $13 \%$ & $56 \%$ & $81 \%$ \\
\hline 2 & Hasil belajar siswa $<7$ & $88 \%$ & $44 \%$ & $19 \%$ \\
\hline
\end{tabular}




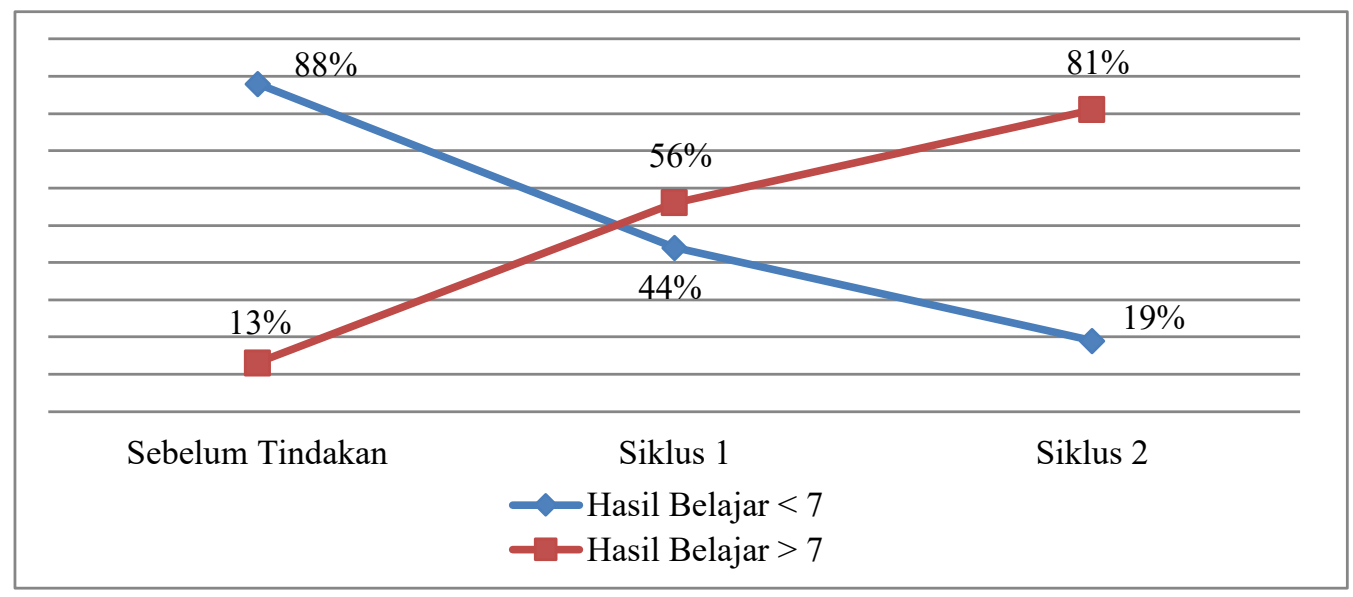

Gambar 1.Grafik Peningkatan Hasil Belajar Siswa.

Berdasarkan data tersebut terlihat siswa dengan nilai lebih dari 7 pada saat sebelum diberi tindakan lebih sedikit dengan nilai persentase hasil belajarnya adalah $13 \%<88 \%$. Pada siklus awal siswa dengan nilai lebih dari 7 memiliki persentase 58\%. Disiklus kedua siswa dengan nilai lebih dari 7 memiliki persentase $81 \%$. Sehingga terlihat bahwa hasil belajar siswa terus mengalami peningkatan.

\section{Pembahasan}

Di awal pembelajaran siswa diminta berdo'a, kemudian mendata kehadiran. Setelah itu siswa diberi gambaran tentang materi dan kemudian guru menyerahkan LKS (Lembar Kerja Siswa) yang akan di diskusikan bersama dua orang. Tyassari (2013) mengatakan kegiatan berdiskusi membuat siswa saling mengeluarkan pendapatnya masing-masing untuk mendapatkan sebuah kesimpulan. Sehingga, kegiatan berdiskusi dapat memudahkan siswa menyelesaikan sebuah permasalahan karena siswa saling berbagi informasi dengan teman sekelompoknya. Dari permasalahan yang diberikan tersebut, guru berharap siswa menemukan konsep dasar mengenai materi jarak pada bangun ruang. Dan guru memberi mereka waktu untuk menyusun informasi dan LKS diselesaikan bersama teman sekelompoknya.

Secara acak guru meminta satu siswa untuk menyampaikan hasil diskusi di depan kelas. Setelah itu, guru bersama siswa membahas kembali permasalahan itu bersama dan kemudian bersama siswa, guru membuat kesimpulan. Guru menutupnya dengan menyerahkan tugas dan kemudian salam.

Berdasarkan pada tabel 1, terlihat bahwa jumlah siswa yang mengalami peningkatan hasil belajar terus meningkat pada setiap siklusnya. Dimana peningkatan hasil belajar siswa sudah mulai terlihat pada siklus pertama dengan jumlah siswa yang mengalami peningkatan adalah sebanyak 18 siswa dari jumlah siswa sebanyak 32 siswa. Sehingga, jumlah siswa yang mendapatkan nilai di atas 7 lebih banyak. Kemudian, pada pemberian tes pada siklus terakhir jumlah siswa yang mendapatkan nilai di atas 7 lebih banyak darp pada tes pertama. Dimana jumlah siswa yang mendapatkan nilai di atas 7 adalah sebanyak 26 siswa dari jumlah seluruh siswa sebanyak 32 siswa. Sehingga pada penelitian ini terlihat bahwa pendekatan problem solving memiliki pengaruh terhadap hasil belajar siswa kelas XII TPTU A. Hasil prenelitian ini diperkuat oleh Zahriah, Hasan, \& Jalil (2016) bahwa proses pembelajaran yang menerapkan problem 
solving, dapat menumbuhkan kemampuan analisis dan juga memperbaiki hasil belajar dan juga membuat siswa menjadi lebih aktif.

\section{KESIMPULAN}

Pada hasil PTK ini, didapatkan bahwa siswa yang menggunakan pendekatan problem solving terus menalami peningkatan hasil belajar pada setiap siklusnya. Dimana persentase jumlah siswa yang mendapatkan nilai di atas 7 terus mengalami peningkatan pada setiap siklusnya. Pada siklus terakhir terlihat bahwa jumlah siswa yang mengalami peningkatan sebanyak 26 siswa dengan nilai di atas 7. Sehingga dapat disimpulkan bahwa pendekatan problem solving memiliki pengaruh pada hasil belajar siswa.

\section{UCAPAN TERIMA KASIH}

Peneliti sangat menyadari pada saat penyusunan artikel ini tidak dapat menyelesaikan tanpa bantuan dari berbagai pihak. Oleh karena itu, pada kesempatan ini peneliti sangat berterimakasih kepada Kepala Sekolah SMK Negeri 1 Cimahi Drs. Daud Saleh, MM, guru mata pelajaran matematika Dra. Hj. Fauziah, seluruh siswa kelas XII Teknik Pendingin Tata Udara B, dan Luvy Sylviana Zanthy, selaku dosen mata kuliah PTK. Atas dukungan beliau, peneliti mampu menyelesaikan penelitian dan penulisan artikel ilmiah ini.

\section{DAFTAR PUSTAKA}

Aritonang, K. T. (2008). Minat dan Motivasi dalam Meningkatkan Hasil Belajar Siswa. Jurnal Pendidikan Penabur, 10(10), 13-15.

Pangestika, A. W. (2015). Peningkatan Kemampuan Penalaran dan Hasil Belajar Melalui Metode Pembelajaran Group Investigation (PTK pada Siswa Kelas X Multimedia B SMK Negeri 9 Surakarta Semester Genap Tahun Ajaran 2014/2015). Universitas Muhammadiyah Surakarta.

Syarif, M. (2017). Pembelajaran Dengan Pendekatan Problem Solving Untuk Meningkatkan Kemampuan Berpikir Kritis Dan Kreatif Matematika Siswa SMA. Jurnal Mutiara Pedagogik, 1(2), 92-101.

Tyassari, A. D. H. (2013). Peningkatan Kemampuan Berpikir Kritis dan Penalaran Siswa pada Matematika dengan Model Pembelajaran Problem Posing (PTK Pada Siswa Kelas VII SMP Muhammadiyah 10 Surakarta Tahun Ajaran 2012/2013). Universitas Muhammadiyah Surakarta.

Zahriah, Z., Hasan, M., \& Jalil, Z. (2016). Penerapan Pemecahan Masalah Model Polya Untuk Meningkatkan Kemampuan Analisis dan Hasil Belajar pada Materi Vektor di SMAN 1 Darul Imarah. Jurnal Pendidikan Sains Indonesia, 4(1). 